$\xi^{2}=$

\title{
Delineating surface and sub surface waterlogged area using RS \& GIS: a case study of Rachna Doab
}

\author{
Hannan Mehmood*, Mobushir Riaz Khan, Muhammad Amin, Rizwan Ali \\ Institute of Geoinformation and Earth Observation, PMAS Arid Agriculture University, Rawalpindi, Pakistan \\ *Corresponding author E-mail: hannanmehmood@yahoo.com
}

\begin{abstract}
Remote sensing (RS) combined with Geographical Information Systems (GIS) offers fabulous contrasting option to routine mapping strategies in observing and mapping of surface and sub-surface waterlogged areas. In the present study, a pre-monsoon and postmonsoon surface waterlogged area was delineated in the four districts of Rachna doab, using Landsat 8 data acquired for the year 2014. Modified Normalized Difference Water Index (MNDWI) was used mainly to delineate surface waterlogged areas. Perennial surface waterlogged areas were assessed for the study area by incorporating the waterlogged areas derived for both the pre-monsoon and postmonsoon seasons under GIS environment. Result shows that the total surface waterlogged area in pre-monsoon is 5,861 ha, which is $0.51 \%$ of study area and for post-monsoon the surface waterlogging is 8,661 ha, which is $0.75 \%$ of study area respectively. Perennial surface waterlogging is 3,573 ha, which is $0.30 \%$ of the study area. Maximum waterlogged area was observed in Gujranwala district followed by Hafizabad, Sheikhupura and Nankana Sahib respectively. Further, waterlogged areas caused by rise in groundwater level were also assessed spatially under ArcGIS environment using the piezometric data pertaining of pre-monsoon and post-monsoon seasons for the year 2014 which were spread all over the study area. The analysis of both the seasons of groundwater levels indicates that the area under critical category during pre-monsoon period was 47,309 ha, which is $4 \%$ of the total area. Area under most critical category during post-monsoon period increased from 47,309 to 131,070 ha, which is $11 \%$ of the total. The study shows utility of remote sensing and GIS for evaluation of waterlogging areas especially where waterlogging situations occurs because of excessive irrigation and accumulation of rain and floodwater.
\end{abstract}

Keywords: Waterlogged Areas; Gis; Rs; Piezometric Data; Rachna Doab.

\section{Introduction}

Pakistan has been blessed for having massive water resources in the form of rivers, snow and Ice Mountains, rainy water and underground water reservoirs. The Indus Basin Irrigation System (IBIS) is an off short of these massive rivers (Ravi, Satluj, Chenab and Jhelum), which enables irrigated land to resource of productive agriculture land (S \& R Publication, 2007). Pakistan economy is heavily dependent on agriculture (Sumia \& Zaman, 2009). Pakistan cannot pay for any loss of agricultural land in one way or the other, as agriculture sector makes up for $20.9 \%$ with the GDP and consumes $43.4 \%$ of the total work power (Govt. of Pakistan, 2007).

The introduction of irrigation system in various countries has reduced waterlogging and salinization for large areas (Al-Khaier 2003). Irrigation is the dire need for the arid regions of Pakistan with respect to accomplishing and maintaining food security. The irrigation system supports 3/4th of overall gross value manufacturing, as rice, cotton, sugarcane, fruits and vegetables can't always be full-grown in absence of adequate quantity of water (Zaman \& Ahmad, 2009). Ineffective irrigation is amongst the root factors that cause salinity and waterlogging. A continuous loss of water in canals and waterways because of poor irrigation outcome in deep water leakage and eventually plays a role to cause soil salinity and waterlogging. Massive irrigation channel is not only a loss of water however it is an additional loss involving fertilizer because of percolating. Pakistan has total area of 79.6 million hectares where
22 million hectares is cultivated (Govt. of Pakistan, 2007), and 6.28 million hectares is affected by soil salinity and waterlogging within the irrigation system (Rafiq, 1990). It is assessed that nearly $25 \%$ of the irrigated land in the Punjab and $40 \%$ in the Sindh are saline. Approximately $10-20$ million people living on salt affected land (Barrett \& Hollington, 2006).

In general, for mapping of waterlogged areas, ground survey technique is used. While looking at national and provincial level, these conventional techniques are very time consuming as well as have a sufficient cost impact. In the past, several studies have demonstrated the usefulness of Remote Sensing and GIS techniques in detecting and monitoring waterlogged and salinization. (Kudrat \& Bhan, 1990) analyzed and mapped the salt affected and waterlogging areas by using Thematic Mapper data in India and found that these areas can be defined and classified with an exactness of about $96 \%$ using bands three to seven. The seasonal waterlogging situation measured as a danger to the local inhabitants as it interrupts the surface transport system. To assessed the small patches of waterlogging areas, satellite remote sensing data may be effective (Dwivedi, 1994). In India, (Choubey, 1998) completed a study on evaluation of waterlogged areas in Sri-ram area by RS and GIS. (Paul 2000) used Landsat 5 TM imageries to identify open water bodies and floodplain of the Murrumbidgee River closed to the city of Wagga Wagga, Australia. They found that optical Landsat is very beneficial for identifying water bodies and floodplain in their study. Normalized Difference Vegetation Index (NDVI) and Normalized Difference Water Index (NDWI) have significant application to identify waterlogged areas. (Sahu 2014) 
using integrated RS \& GIS in order to identify waterlogged areas in the Purba Medinipur region of Keleghai river basin, India. Lastly, he used a statistical study that showed a strong correlation between waterlogged areas and canal density.

In this study, primary objective is to identify and analyze the surface and sub-surface waterlogged area by using the RS and GIS. For this purpose, USGS Landsat imagery and piezometric reading data will be processed using ESRI Desktop ArcGIS and Erdas Imagine. Modified Normalized Difference Water Index (MNDWI) has been employed for mapping of surface waterlogged areas. While Inverse distant weighted (IDW) technique is used for interpolating ground water observation well locations.

\section{Study area}

In this research, four districts including Sheikhupura, Gujranwala, Hafizabad and Nankana Sahib was selected as study area. These districts are located between Rachna Doab. Rachna Doab is middle area of River Chenab and River Ravi by extent $\left(75^{\circ} 20^{\prime} 32.245^{\prime \prime} \mathrm{E} \quad 32^{\circ} 58^{\prime} 18.321^{\prime \prime N}\right) \quad$ and $\quad\left(71^{\circ} 48^{\prime} 31.646^{\prime \prime} \mathrm{E}\right.$ $30^{\circ} 29^{\prime} 41.053 " \mathrm{~N}$ ) (Figure 1). Nearly 2.3 million hectares cultivated land area and 2.98 million hectares gross area in Rachna Doab. Rachna area consist two agro climatic zones, Rice Wheat zone and sugarcane wheat zone (WAPDA, 1979).

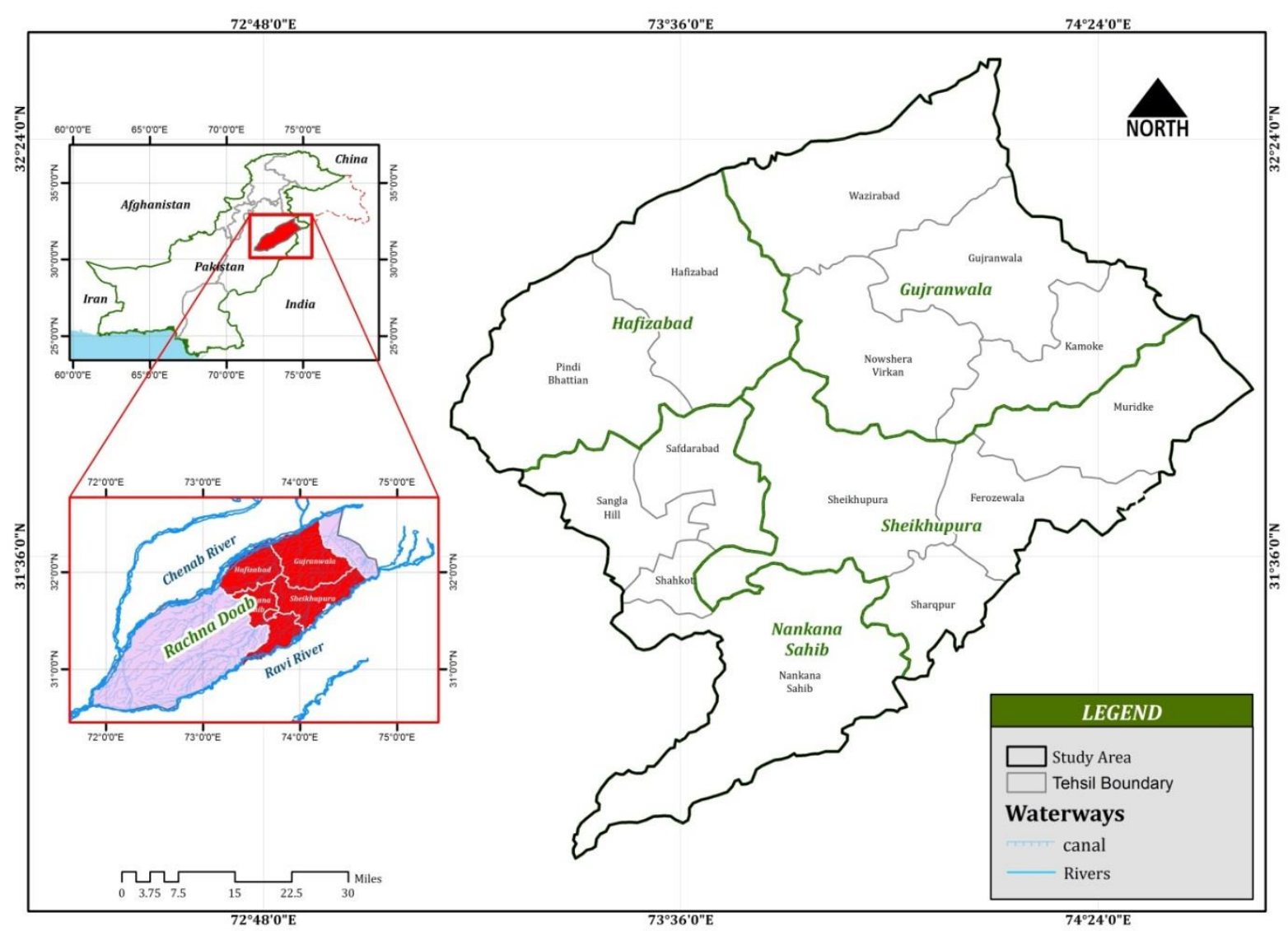

Fig. 1: Study Area.

Total area of these four districts is $\left(11,698 \mathrm{~km}^{2}\right)$ and nearly 31 percent of it contains by Gujranwala District, and 26, 24, 19 situated in Sheikhupura, Nankana Sahib, Hafizabad, respectively (Table 1). The temperature of the region is warm and dry during summer and cold in winter.

The summer starts in April and continues till October temperature range during these months are $21{ }^{\circ} \mathrm{C}$ to $50{ }^{\circ} \mathrm{C}$. During winter temperature remains pleasant range for temperature is $15-27{ }^{\circ} \mathrm{C}$ for daytime and $7-27^{\circ} \mathrm{C}$ at night. Annual mean precipitation is 1,080 $\mathrm{mm}$ to $340 \mathrm{~mm}$ from northern areas to southern respectively. Monsoon rains duration is from July to August. The rainfall has significant effects for hydrology and agriculture for areas.
Remote sensing data from Landsat 8 (Operational Land Imager) for the year 2014 was used for the delineation and mapping of pre and post monsoon surface waterlogging areas (Table 2). These passive Landsat data was collected and download from the USGS (U.S Geological Survey) free of cost. Landsat 8 scene data consists of Eleven Spectral bands in which four bands are extracted here in study that corresponds to green $(0.53-0.59)$, Red $(0.64-$ $0.67)$, Near Infrared(0.85 - 0.88) and Short wave infrared(1.57 $1.65)$. The spatial resolution of each scene is 30 meter. False color composite (FSS) consisted of three bands NIR, R and G bands for identification of pre and post monsoon surface waterlogging areas in the study area.

Table 1: General Distribution of the Study Areas

\begin{tabular}{llll}
\hline Area & \multicolumn{2}{l}{ Distribution of Study Area } & Population density \\
\hline Districts & (Sq. Km) & Percentage & (Million persons) \\
Gujranwala & 3,621 & 31 & 3.374 \\
Sheikhupura & 3,030 & 26 & 3.232 \\
Hafizabad & 2,273 & 19 & 0.822 \\
Nankana Sahib & 2,773 & 24 & 0.07 \\
Total & 11,698 & 100 & 7.498 \\
\hline
\end{tabular}

Table 2: Metadata of Remote Sensing Data

\begin{tabular}{lllll}
\hline S.no & Path & Row & $\begin{array}{l}\text { Satellite data Acquisition } \\
\text { date }\end{array}$ & Resolution \\
\hline 1 & 149 & 38 & 03.04 .2014 & 30 \\
2 & 149 & 38 & 12.10 .2014 & 30 \\
\hline
\end{tabular}

\subsection{Piezometric data}

\section{Data used}

\subsection{Remote sensing data}

To estimate the sub-surface waterlogging areas caused by increase in the water table depth near to ground surface. The Piezometric readings data was acquired for the period of pre and post monsoon 
for the year 2014 for all the observation wells, monitored and observed by Water and Power development authority (WAPDA). The observation wells are spread all over the study area (Figure 2).

\subsection{Collateral data}

Administrative dataset downloaded from the UNOCHA geospatial data sharing portal, which is in the shape file format. Temporal resolution of this dataset is 2014 .

\section{Methodology}

\subsection{Mapping of surface waterlogging}

In this study, Modified Normalized difference water Index (MNDWI) method was used for delineating the water bodies and to simultaneously eliminate the soil and vegetation features.

The index (McFeeters, 1996) is calculated as follow:

$$
\text { MNDWI }=(\text { GREEN }- \text { MIR }) /(\text { GREEN }+ \text { MIR })
$$

Its value ranges from -1 and +1 . The positive and negative values in a MNDWI indicate the water bodies and vegetation cover because of higher reflectance of MIR and Green band.

The resulting ratio images were classified into series of specified intervals for delineating waterlogging areas and saturated areas. For segregating the resulting images, MNDWI values were need to be defined for each data. In this study, it is found that the threshold value of MNDWI value is 0.1 , which is defined for segregating the waterlogging areas.

The value from $0-0.1$ indicates the presence of dry or wet soil. Figure 2 represented the methodology for assessment of surface and sub-surface. False color composite (FSS) consisted of three bands NIR, R and $\mathrm{G}$ bands was also used for the identification or assessment of pre and post monsoon surface waterlogging areas.

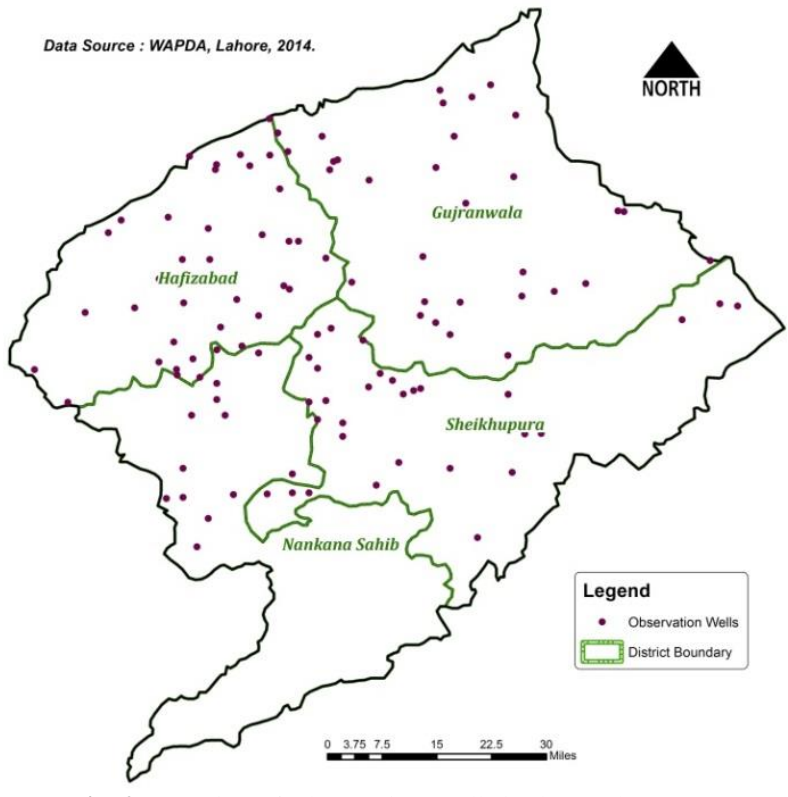

Fig. 2: Location of Observation Wells in the Study Area.

\subsection{Delineation of sub-surface waterlogging}

Piezometric readings that were taken from WAPDA is scattered and in rough format, some data cleaning has been made on it so that it would be easily available / accessible in ArcGIS Environment. i.e. removed spaces and special characters. All missing values or an observation well that was closed are removed and readings were taken only for operational wells. All these changes were required before opening/adding these data into ArcGIS Environment to create a point coverage shape file with desired projection. After creating the point coverage shapefile that was consistent in all aspects, attributes such as ground water depth for pre and post monsoon were interpolated spatially using the ArcGIS. The output $\mathrm{grid} / \mathrm{cell}$ size is generated of $30 * 30 \mathrm{~m}$.

To select the best interpolation technique in study area, observation wells was divided randomly into two groups including training set (80\%) and validation set (20\%), respectively. Various interpolation techniques were performed for analyzing the output grid result. Afterwards, the interpolation values are compared with the validation dataset. IDW perform significantly different and had low resistance. The IDW produce the better result for the study area. Hence the IDW is selected for the study area and also analyzed that, observation well location is distributed uniformly in the area.

The IDW created ground water grid/cell was reclassified into different classes. The class that containing less than three meters is considered to be a waterlogged area as per wapda's criteria 


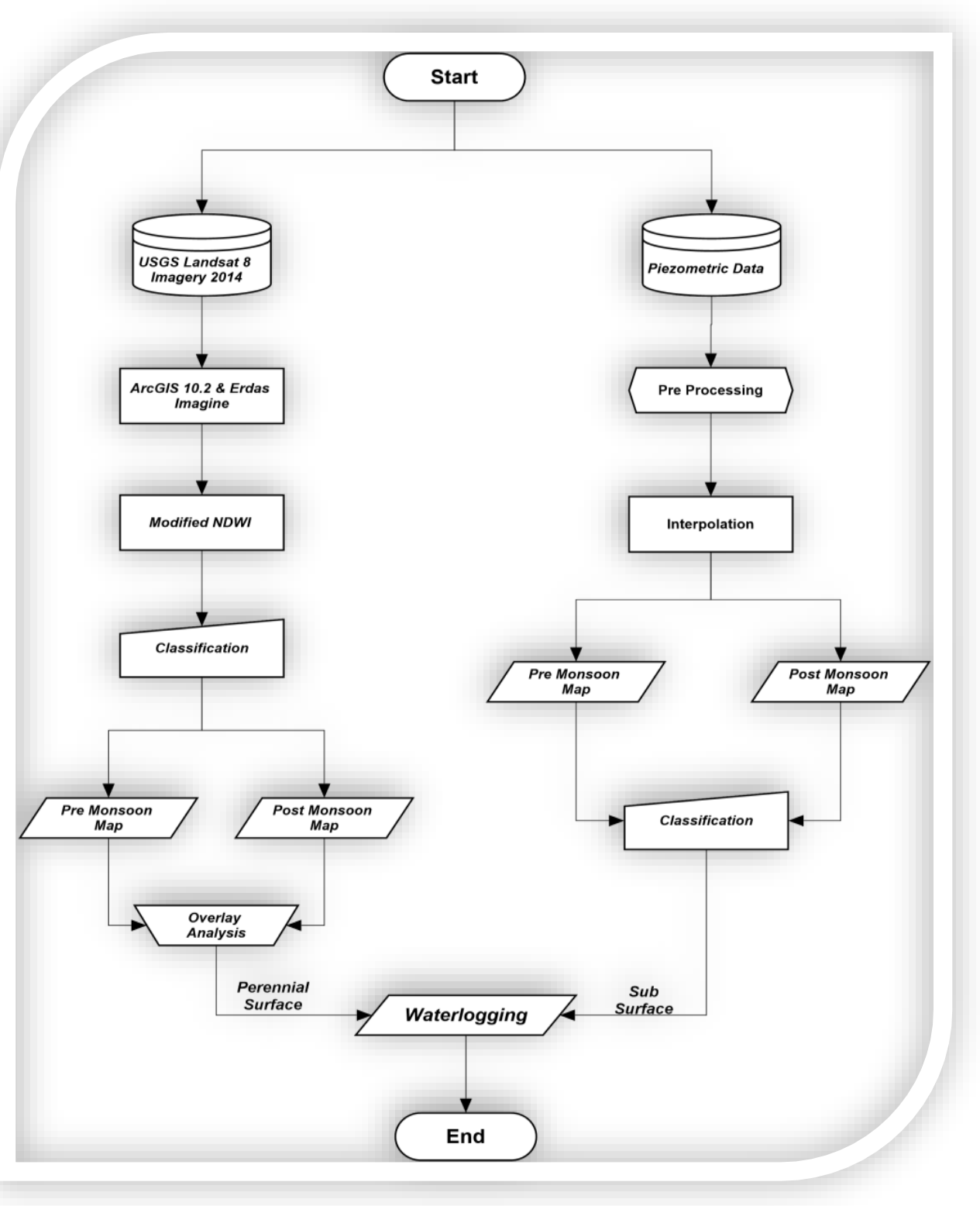

Fig. 3: Workflow Diagram.

\section{Results \& discussion}

In this present study, pre monsoon and post monsoon perennial surface waterlogging was delineated for all the four districts of rachna doab. The areas where land remains waterlogged throughout the year is termed as perennial waterlogging. Further, districts wise perennial surface waterlogged area is estimated using ArcGIS Environment.

It is observed, that study area has less than $1 \%$ perennial surface waterlogged area shown in (Figure 4). If we consider different stage than remaining $99 \%$ waterlogging is seasonal.

From the analysis it is observed that 5,861 hectares area is under waterlogging condition in pre monsoon duration which is $0.51 \%$ of the total study area. While the area is in post monsoon duration is increased and goes to 8,661 Hectares which is $0.75 \%$ of the total study area. The perennial surface waterlogged area is $3,573 \mathrm{Hec}-$ tares which is $0.3 \%$ of the total as presented in (Table 3 ).
Table 3: District Wise Perennial Surface Waterlogged Area Calculations

\begin{tabular}{ll}
\hline Area & Hectares \\
Districts & 1,633 \\
\hline Gujranwala & 670 \\
Sheikhupura & 861 \\
Hafizabad & 409 \\
Nankana Sahib & 3,573 \\
Total & \\
\hline
\end{tabular}

The buffer zone analysis on perennial surface waterlogging areas was also performed to assess the effects of rivers, canals on study area. Buffers zones were generated on 500, 1000, and 1500, 2000 and greater than 2000 meters to check the area distribution of waterlogging areas shown in (Figure 5).

It is analyzed that almost $30 \%$ of the perennial waterlogging is due to seepage of canal irrigation water and remaining is because of low lying areas that the water runoff affected and it form the lakes and other is due to industrial chemical waste water on the land.

Further, waterlogged areas due to rise in ground water level for both pre and post monsoon seasons was also assessed, and mapped the critical areas in term of ground water level for year 2014 were shown in (Figure 7 a \& b).

Analysis of pre and post monsoon indicates that 47,309 hectares is waterlogging in pre monsoon which is $4 \%$ of the total and 131,070 hectares is under the waterlogging condition in post monsoon 
season which is $11 \%$ of the total area. It is analyzed that almost $70 \%$ of the sub surface waterlogging areas (less than 3 meters) and the zones near to waterlogging $(3-4.5$ meters $)$ are matched with the perennial waterlogging areas obtained by using the RS results.

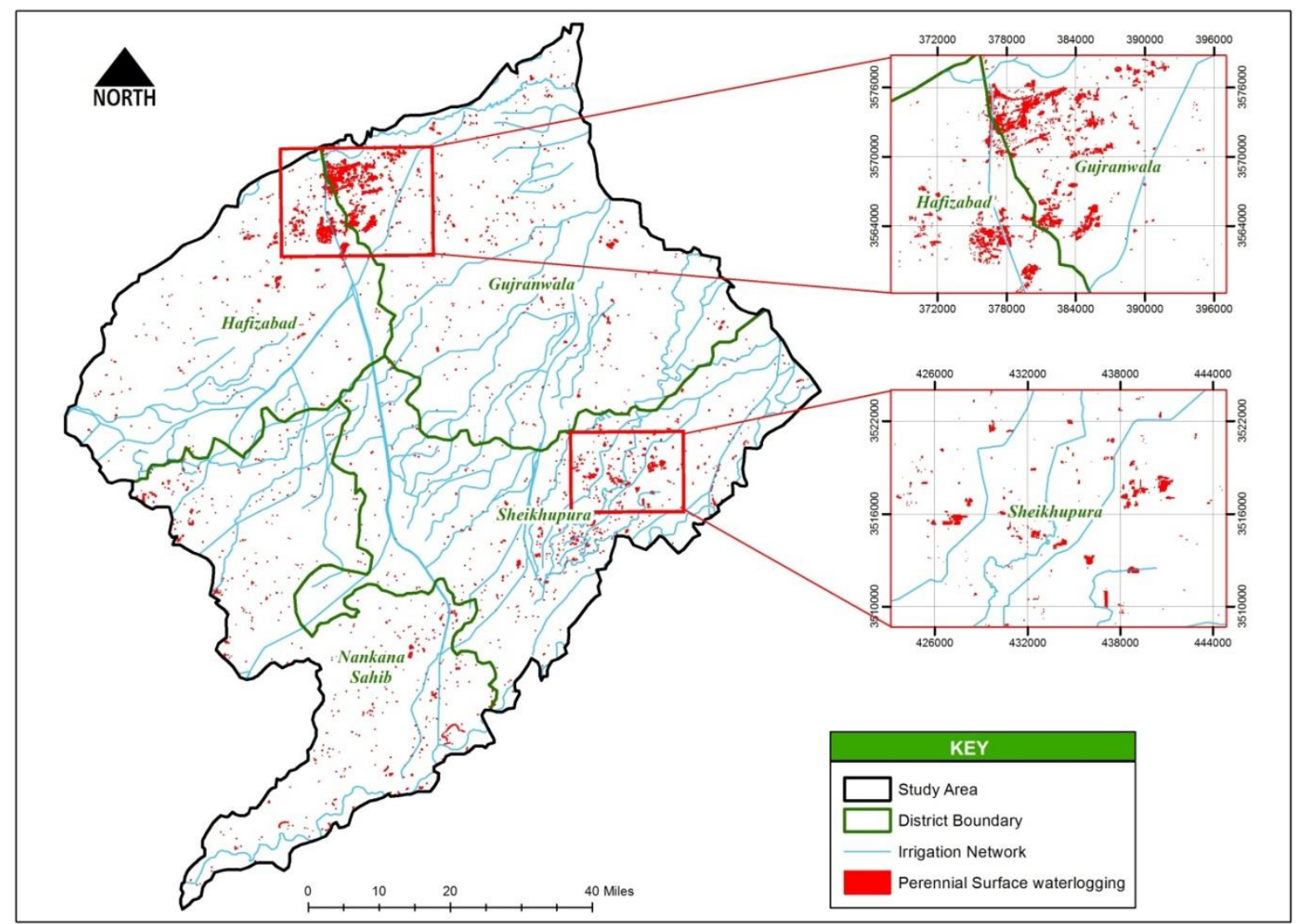

Fig. 4: Integrated Map Overlaid with District Boundary and Irrigation Network Showing Perennial Surface Waterlogged Area 2014.

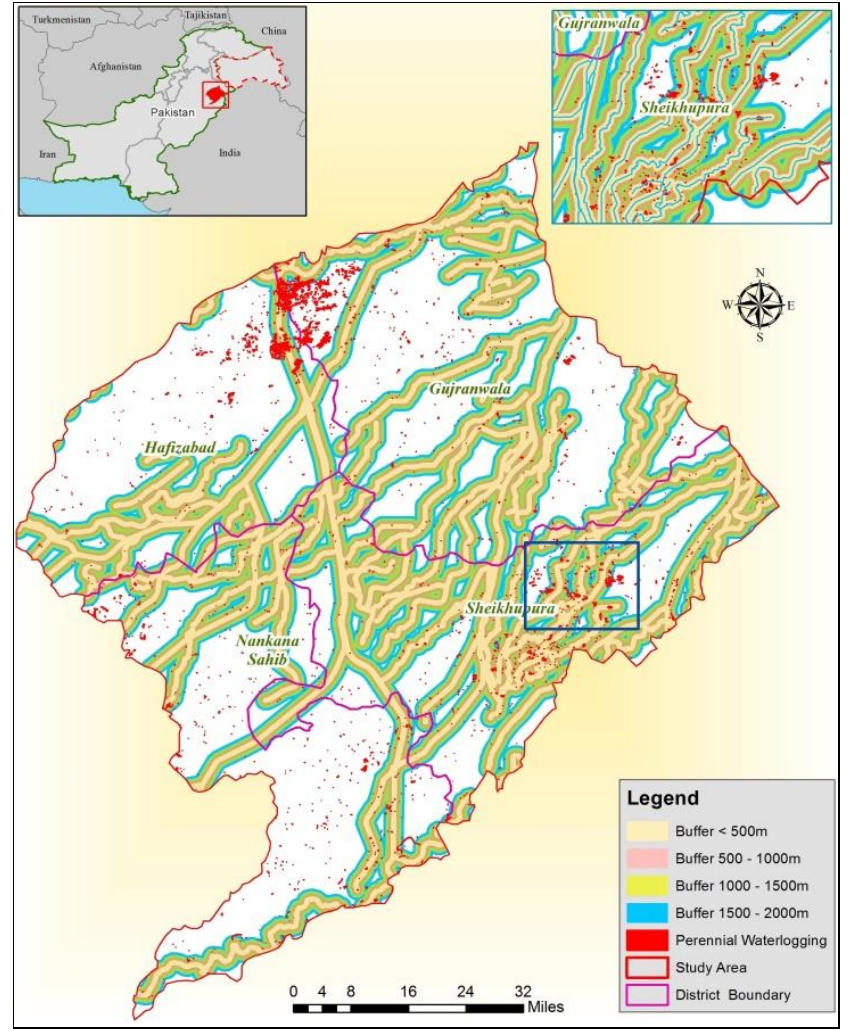

Fig. 5: Buffer Analysis on Perennial Surface Waterlogging Areas. 


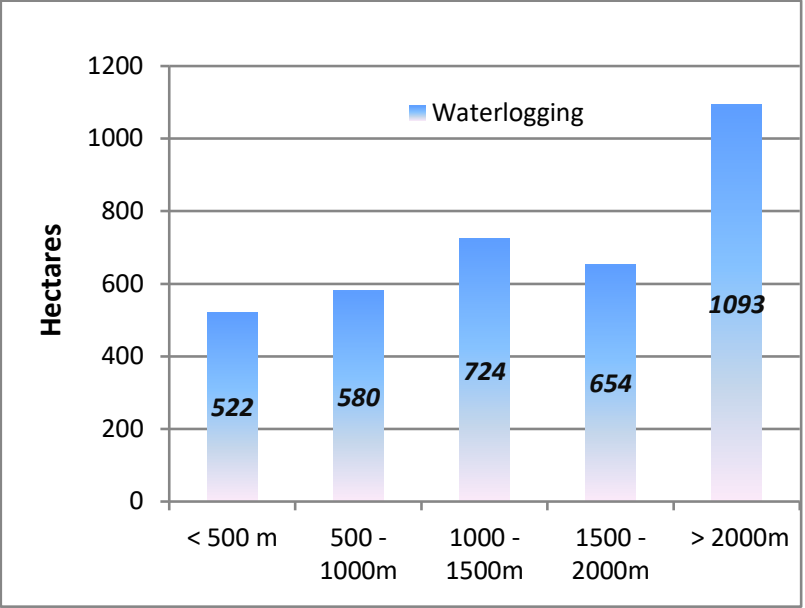

Fig. 6: Perennial Surface Waterlogging Distribution on Buffer Zones.

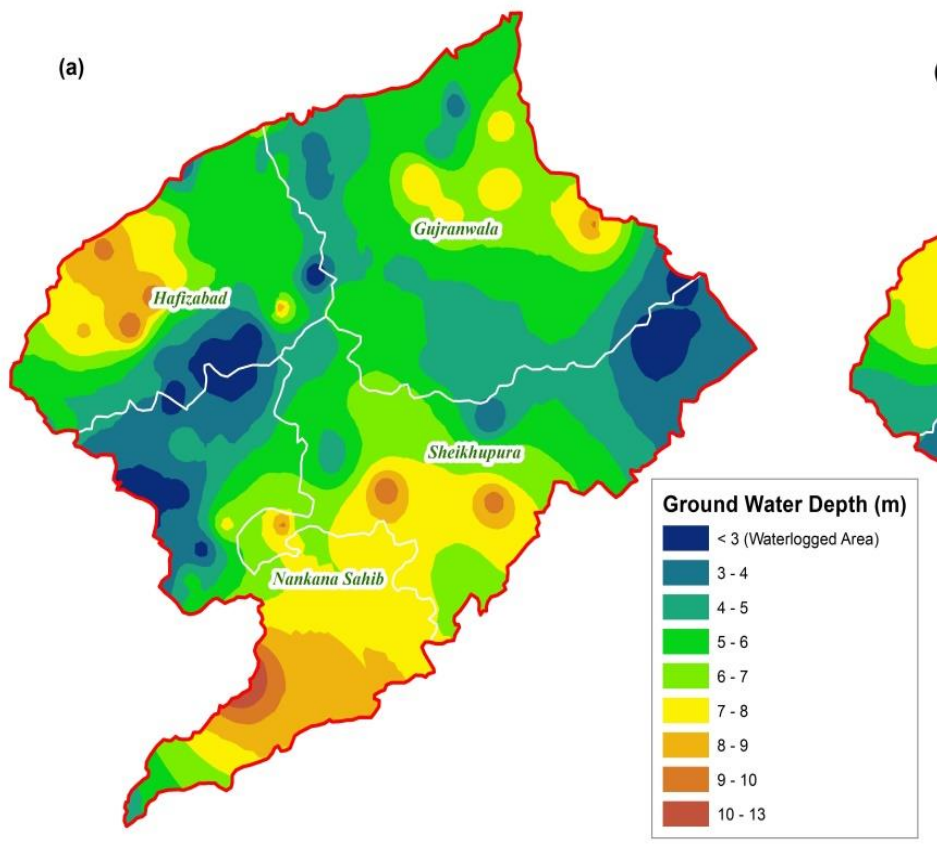

(b)

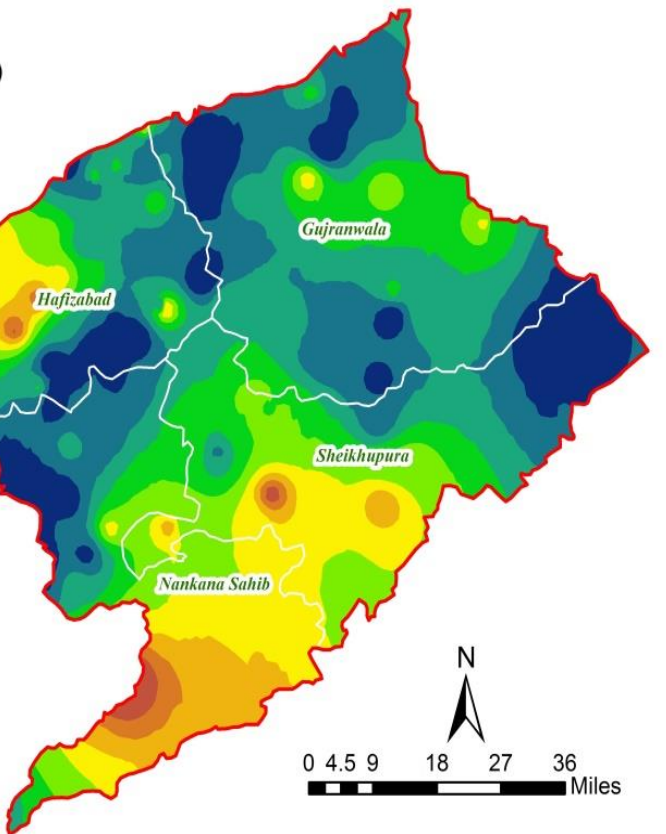

Fig. 7: Sub-Surface Waterlogging Areas (In Terms of Ground Water Depth): (A) Pre-Monsoon (June 2014), (B) Post-Monsoon (October 2014).

\section{Conclusion}

Reliable assessment of waterlogged areas forms a significant component in the study area development program. In this present study, Landsat 8 imagery was effectively utilized for assessment of waterlogging areas in order to assess the consequence of canal network. However, the study ought to be carried out at regular interval to observe the more progression of the phenomena. Such analysis is supportive to the stakeholders and administrators for implementing corrective measures without utilizing the large work force.

Landsat imageries were shown to be a useful to detect waterlogged areas in this study. Using Landsat 8 (30 meter) passive data for extracting water bodies can be viable. Normalized difference water index (NDWI) and Modified normalized difference water index (MNDWI) were also appropriate for generating lucid information for water bodies. In this study, some other important environmental and socio-economic data have not used. Therefore, such kinds of data are recommended for further research on the field in the study area.Hyperspectral data having optical region of spectrum \& microwave data could also be useful for detail assessment of hydrological situations of irrigated land.

\section{Acknowledgements}

I gratefully acknowledge Dr. Hamid Mehmood, Adjunt faculty (Institute of Space Technology) for providing necessary support for carrying out this research. Without their help it would not be possible to collect the information from Wadpa about ground water data.

\section{References}

[1] A.M.Omer, "Sustainable water resources management, future demands and adaptation strategies in Sudan," Journal of Environmental Science and Water Resources, vol. 1, no. 7, pp. 151-168, 2012.

[2] Ashraf, A., \& Ahmad, Z., Integration of Groundwater Flow Modeling and GIS, Water Resources Management and Modeling, 2012, 239-62. https://doi.org/10.5772/34257.

[3] Aslam, K., Use of Geospatial Technology for Assessment of Waterlogging \& Salinity Conditions in the Nara Canal Command Area in Sindh, Pakistan, 2015, 438-47.

[4] Bastawesy, M. El., Assessment of Waterlogging in Agricultural Megaprojects in the Closed Drainage Basins of the Western Desert of Egypt, Hydrology and Earth System Sciences, 17.4 (2013), 1493-1501. https://doi.org/10.5194/hess-17-1493-2013.

[5] Chatterjee C, Kumar R, Chakravorthy B, Lohani AK \& Kumar S (2005) Integrating remote sensing and GIS techniques with groundwater flow modeling for assessment of waterlogged areas. 
Water Resource Management 19, 539-554. https://doi.org/10.1007/s11269-005-2071-4.

[6] Choubey, V.K. (1996) Assessment of waterlogged area in IGNP Stage-I by remotely sensed and field data. Hydrology Journal, Vol. XIX (2), pp. 81-93.

[7] Chowdary, V. M., Assessment of Surface and Sub-Surface Waterlogged Areas in Irrigation Command Areas of Bihar State Using Remote Sensing and GIS, Agricultural Water Management, 95.7 (2008), 754-66. https://doi.org/10.1016/j.agwat.2008.02.009.

[8] Chughtai, M.I., \& Mahmood, K., Semi-Intensive Carp Culture in Saline Water-Logged Area: A Multi-Location Study in Shorkot (District Jhang), Pakistan, Pakistan Journal of Zoology, 44.4 (2012), 1065-72.

[9] E. H. Wilson \& S. A. Sader, "Detection of forest harvest type using multiple dates of Landsat TM imagery," Remote Sensing of Environment,vol. 80, no. 3, pp. 385-396, 2002. https://doi.org/10.1016/S0034-4257(01)00318-2.

[10] Ehlers, M.; Edwards, G. \& Bedard, Y. (1989) Integration of Remote sensing with Geographic Information Systems: A Necessary Evolution. Photogrammetric Engineering and Remote sensing, 55, no. 11: 1619-1627.

[11] Hassan, Md.S., \& Syed Mahmud, S.I., Detection of Waterlogging Areas Based on Passive Remote Sensing Data in Jessore District of Khulna Division, Bangladesh, International Journal of Scientific and Research Publications, 4.12 (2014), 1-7.

[12] J. Holden, A. J. Howard, L. J. West, E. Max eld, I. Panter, \& J. Oxley, "A critical review of hydrological data collection for assessing preservation risk for urban waterlogged archaeology: a case study from the City of York, UK," Journal of Environmental Management, vol. 90,no. 11, pp. 3197-3204, 2009 https://doi.org/10.1016/j.jenvman.2009.04.015.

[13] Kaiser, M. F., GIS Data Integration to Manage Waterlogging Problem on the Eastern Nile Delta of Egypt, International Journal of Geosciences, $\quad 04.04 \quad$ (2013), 680-87. https://doi.org/10.4236/ijg.2013.44063.

[14] Lodhi, T.E., Impact of the social mobilization efforts on community development through the rehabilitation of saline sand, 42 (2005), 97-99.

[15] Merot Ph, Ezzahar B, Walter C \& Aurousseau P (1995) Mapping Waterlogging of Soils using Digital Terrain Models. Hydrological Processes 9, 27-34. https://doi.org/10.1002/hyp.3360090104.

[16] Quan RS, Liu M, Lu M, Zhang L, Wang J \& Xu S (2010) Waterlog-ging Risk Assessment Based on Land Use/Cover Change: a Case Study in Pudong New Area, Shanghai. Environ Earth Sci 61, 1113-1121. https://doi.org/10.1007/s12665-009-0431-8.

[17] Qureshi AS, McCornick PG, Qadir M \& Aslam Z (2008) Managing Salinity and Waterlogging in the Indus Basin of Pakistan. Agricultural Water Management 96(1), 1-10. https://doi.org/10.1016/j.agwat.2007.09.014.

[18] S. F. Paul \& J. Kenneth, "Water Body Detection and Delineation with Landsat TM Data," Photogrammetric Engineering \& Remote Sensing, Vol. 66, No. 12, December 2000, pp. 1461-1467.

[19] Sahu, A.S., Identification and Mapping of the Water-Logged Areas in Purba Medinipur Part of Keleghai River Basin, India: RS and GIS Methods, 2.2 (2014), 59-65.

[20] WAPDA (1993) Pakistan Drainage Sector Environmental Assessment - National Drainage Programme Vol. 4: (Data (water, Soil and Agriculture), NESPAK and Mot MacDonald Int. Ltd., WAPDA, Lahore, Pakistan.

[21] Xu H (2006) Modification of Normalised Difference Water Index (NDWI) to enhance open water features in remotely sensed imagery. International Journal of Remote Sensing 27(14), 3025-3033. https://doi.org/10.1080/01431160600589179.

[22] Xu, H., Modification of Normalised Difference Water Index (NDWI) to Enhance Open Water Features in Remotely Sensed Imagery, International Journal of Remote Sensing, 27.14 (2006), 3025-33.

[23] Zaman, S.B \& Ahmad, S., Salinity and Waterlogging in the Indus Basin of Pakistan : Economic Loss to Agricultural Economy, Managing Natural Resources for Sustaining Future Agriculture, Research Briefings, $1.4 \quad$ (2009), $1-10$ https://doi.org/10.1080/01431160600589179. 